\title{
AN ANALYSIS OF THE EUROPEAN PRACTICES IN BULGARIA TO SUPPORT START-UPS
}

\author{
Tsvetana STOYANOVA, Miglena ANGELOVA \\ University of National and World Economy, Sofia, Bulgaria \\ tsvetana_stoyanova@unwe.bg; m.angelova.phd@gmail.com
}

\begin{abstract}
The dynamics of modern business life due to a faster development of innovations and technologies is able to turn over for a very short period the logic and development of entire economic sectors. The power and traditions of well-known companies can be challenged by the fundamentally new services and products developed by the small team of a start-up. This is the reason that these companies are in the focus of the European policy. Start-ups could gain competitive advantages of the European economy through fundamentally new products and services mainly in the high technologic branches. This report presents the analysis of the European practice in Bulgaria to support start-ups as an instrument to gain competitive advantage. The analysis includes European framework policy for start-ups and its implementation and results in Bulgaria.
\end{abstract}

Keywords: Start-ups; Business angels, Business incubators, Business Accelerators, Start-ups Ecosystem

\section{Introduction}

In today`s rapidly changing and dynamic economic life, the survival of companies is subjected under different challenges. Uncertainty and unpredictability of the external environment which also reflect the high level of risk in making managerial decisions, further reduce the opportunities for small and medium-sized enterprises. When we consider the situation about startup companies, their perspectives become even bleaker. The difficulties they faced are incomparably larger than business organizations with past experience. Startups have to fight at the same time in several directions - from one hand this is the external environment, with all the strength of competition, besides - they have to compete with players with developed market positions and loyalty of their clients. While they are trying to get into the market, start-ups have to arrange in-house organization things, which sometimes is as difficult task as the previous one, concerning external environment. Adding to this complicated circumstances also and the problems, related to the initial finding of financial resources (that are lifesustaining for start-ups) we can clearly realize why the huge percentage of them cannot survive during the first year of their lives.

Start-ups become recently well-observed focus on scientific researches in different lights - from technology, through funding and ways of survival $[1,2,3,4,5,6,7,8]$. However, having in mind that start-ups are the generator and the catalyst of nontraditional and unconventional ideas that could reverse the logic of a whole industry, the European Union has special policy for start-ups in order to support them during these early and crucial stages of their development. 
2. The role and significance of the startups for the economy development

\subsection{The start-ups in Bulgarian context}

Bulgaria as a member-state of the European Union has already seven years of experience during first programming period in supporting small and medium-sized enterprises, including special policy for startups.

Data of the National Strategy for SMEs Promotion - Small Business Act for the period 2014-2020 show interesting facts on the start-up situation [8]. For instance, in the top 10 sectors of the Bulgarian Economy by numbers of start-up SMEs there is no one industrial - they all are in the service sectors (Table.1).

Table 1 Top 10 Bulgarian Economy sectors by number of start-up SMEs Source: National Strategy for SMEs Promotion 2014-2020

\begin{tabular}{|l|l|c|}
\hline \multicolumn{1}{|c|}{$\mathbf{N}$} & \multicolumn{1}{|c|}{$\begin{array}{c}\text { Name of the } \\
\text { sector }\end{array}$} & $\begin{array}{c}\text { Number of } \\
\text { start-up in } \\
\mathbf{2 0 1 1}\end{array}$ \\
\hline 1. & Retail & 10,608 \\
\hline 2. & Wholesale & 3,540 \\
\hline 3. & Restaurants & 3,070 \\
\hline 4. & Real Estate & 2,537 \\
\hline 5. & Land Transport & 1,893 \\
\hline 6. & $\begin{array}{l}\text { Wholesale and } \\
\text { retail of motor } \\
\text { vehicles, } \\
\text { motorcycles etc. }\end{array}$ & 1,228 \\
\hline 7. & $\begin{array}{l}\text { Specialised } \\
\text { construction } \\
\text { activities }\end{array}$ & 1,073 \\
\hline 8. & $\begin{array}{l}\text { Other professional } \\
\text { activities (design, } \\
\text { photography, } \\
\text { translations) }\end{array}$ & 1,007 \\
\hline 9. & $\begin{array}{l}\text { Legal and } \\
\text { accounting } \\
\text { activities }\end{array}$ & $\begin{array}{l}\text { Construction of } \\
\text { buildings }\end{array}$ \\
\hline 10. & \multicolumn{2}{|l|}{792} \\
\hline
\end{tabular}

This situation for Bulgarian start-ups in fact largely repeats the structure of the Bulgarian Economy, where the share of companies operating in the Retail sector is $32 \%$ (in contrast with the European Economy - where the share of enterprises in retail sector is average 17\%). The data also shows that the first three industrial sectors with most start-ups are: manufacture of clothing, food and metal products, occupying respectively the 14th, 15 th and 22nd place with 457, 449 and 214 new businesses.

It is indisputable that staring a new business in production is accompanied by the need of serious financial resources especially in the first few months, which fact immediately increase the risk of investments. This could be one of the reasons to explain the backwardness of the industrial sectors in terms of discussed indicator.

However, considering that the production companies are these that create a large part of value added in the economy, we have to worry about this kind of ranking. On the other hand it is a base that create the necessity of a targeting strategic governmental policy to support start-ups in key industrial Bulgarian economic sectors (of course in accordance with the European Regulations and politics).

\subsection{Lessons learnt from the programming period 2007-2013}

During the first programming period for Bulgaria as a member state of the European Union, the Operational Programme Development of the Competitiveness of the Bulgarian Economy was the programme dedicated to the needs of enterprises. Approximately $30 \%$ of the budget of the programme was allocated for the financial instrument in order to help development of the enterprises.

Two funds for initial funding (and total budget of 21 million euro) are supported under JEREMIE initiative. They have provided 73 innovative start-ups with almost 4,4 million euro. Under JEREMIE initiative are implemented also two instruments for facilitating bank lending guarantees, covering losses on portfolios of 
loans and risk sharing financing. The major goal of these two instrument was to provide access to financial resources by making easier the conditions for bank landing. The initial expectation of the specialists were that these financial instruments will provide Bulgarian business with the financial comfort needed to focus on strengthening the market positions through investments in new technologies, equipment, innovation etc.

According to the reports from the Managing Authority of the OP Competitiveness within the Ministry of Economy and also the reports of JEREMIE, the achieved results until the end of the previous programming period are really interesting and deserve deeper analysis (Table 2).

Table 2 Financial instrument distribution for OP Competitiveness 2007-2013 Source: Ministry of Economy, December 2013

\begin{tabular}{|l|l|c|c|c|c|}
\hline $\mathbf{N}$ & $\begin{array}{l}\text { Type of the financial } \\
\text { instrument }\end{array}$ & $\begin{array}{c}\text { Portfolio } \\
\text { Total } \\
\text { value }\end{array}$ & $\begin{array}{c}\text { Funds from OP } \\
\text { Competitiveness }\end{array}$ & $\begin{array}{c}\text { Invested } \\
\text { Funds, Loans, } \\
\text { guarantees }\end{array}$ & $\begin{array}{c}\text { Percentage } \\
\text { of } \\
\text { absorption }\end{array}$ \\
\hline 1. & Venture capital fund & 20.4 & 14.3 & 0 & $0 \%$ \\
\hline 2. & $\begin{array}{l}\text { Guarantees covering } \\
\text { the losses on a } \\
\text { portfolio of loans }\end{array}$ & 301 & 60.2 & 275 & $91 \%$ \\
\hline 3. & Mezzanine fund & 60 & 30 & 0 & $0 \%$ \\
\hline 4. & $\begin{array}{l}\text { Instrument for } \\
\text { promoting } \\
\text { entrepreneurship and } \\
\text { providing initial } \\
\text { funding }\end{array}$ & 21.21 & 21 & 4.5 & $23.6 \%$ \\
\hline 5. & $\begin{array}{l}\text { Instrument providing } \\
\text { risk sharing financing }\end{array}$ & 400 & 200 & 170 & $42.5 \%$ \\
\hline & Total & $\mathbf{8 0 2 . 5}$ & $\mathbf{3 2 5 . 5}$ & $\mathbf{4 5 0}$ & $\mathbf{5 6 \%}$ \\
\hline
\end{tabular}

According to the analysis made by the Managing Authority of the OP Competitiveness 2007-2013: "The absorption of $56 \%$ of the instruments, which means a significant progress, considering the delayed start of the Programme. In terms of absorption the most successful is the guarantee instrument (91\% at end of 2013). Given the fact that the instruments for risk sharing actually began operating in 2013 the rate of $42.5 \%$ achieved also outlines good perspectives. The actual operations of the VC fund and Mezzanine funds are about to start. With respect to the Mezzanine fund, the investors expect future guarantees of the instrument." [9].

The level of implementation of these financial instruments allows Managing Authority of the programme to conclude the following: "Considering the success of the financial instruments and the fact that aid under OP, aimed at this type of tools, leads to significant mobilization of private capital, under OPIC will be provided their operation and in the next programming period, taking into account the need to ensure a sufficient volume of public information about the progress of the financial instruments, the selection of financial intermediaries and the level of achievement of their objectives. The size of the portfolio and type of instruments, which will continue to be funded are determined based on the results of the use of financial instruments by OPIC under art. 37 of the (EU) Regulation No.1303 / 2013, which provides an assessment of market failure or sub-optimal investment situation in the 
country and the estimated level and scope of public investment needs." [9].

\subsection{Situation during the present programming period 2014-2020}

During the present programming period Bulgaria has two programmes especially for business - Operational Programme Innovation and Competitiveness (with total budget of 1186727749 euro) and SME initiative Programme (with total budget of 102 million euro).

Respecting the EU policy of using more financial instrument, whole SME initiative Programme is implemented through financial instruments by European Investment Fund with one major goal - to enhance the access to debt finance for SMEs in Bulgaria.

Under OPIC there is one procedure "Support for development of innovation by start-ups" which is in implementation with total budget of approximately 16 million euro. But also under OPIC there are financial instruments with total budget of 135 million euro.

As we can see from this data - the focus this programming period is on the financial instruments for business and special initiative for the innovative startups in grants.

\subsection{Start-up ecosystem in Bulgaria}

First six years after its launch, we could claim that the Bulgarian eco-system for start-ups achieves really positive results. We have business incubators, business angels, manager funds (Eleven and LAUCHub mainly) and of course - first enterprises that successfully pass seed phase. But most important during these years is the formation of special organizational culture - for business entrepreneur - to understand that not everyone and everywhere is a competitors. For business angels - to realize which idea is worth it and deserve the efforts, time and risk to invest in it. For all players - to share good experience and lessons learnt.

\section{Financial instruments versus grant funding - perspectives for start-ups}

Taking into account the rapid development of the financial instruments (according to data from representative of the European Court of Auditor - "the use of financial instruments is becoming increasingly widespread. For the period from 1994 to 1999 only EUR 0.6 billion were spent from the European budget using financial instruments while for the period from 2007 to 2013 they have reached EUR 16 billions. [10]) the Brussels policy will become extremely obvious. Financial instruments have numerous advantages from the European administration point of view but more significant of them could be summarized as follows:

- The resources under financial instruments are provided into intermediaries (most of them banking institutions) that have the needed experience, built human capacity and last but not least - the purely market interest to use and absorb all provided resource to the final beneficiaries - small and medium sized enterprises;

- Projects, funded through financial instruments are more effective in order to recover the made public investments.

- They attract further private capital and this is the reason that the effect of each invested euro cent increase significantly through the financial instruments.

When in this circumstances we also add the fact that through financial instruments the local/regional/national authorities are relieved of activities that are not relevant to them such as assessing, for example, the capacity and competitiveness of business organizations, benefits of using the financial instrument instead of grant financing from public administration's point of view are really impressive.

At the same time, we have to consider that while the global economic and financial crisis is waning, the European Union is forced to implement more and more rigorous financial discipline and take into 
account the real benefits that any euro cent can bring. The goal is clear for the European Union - to achieve a competitive economy on a global scale such as USA and China.

On the other hand, the advantages for the business using grant funding are huge:

- Bulgarian companies have already culture and experience in preparation and implementation project, funded by the European funds

- Grant does not require returning financial resources - an exceptional benefit, especially when we talk about renovation of technical equipment of the Bulgarian companies where the needed investments are really big

- There is no risk for beneficiary organization from the point of view of financial commitment. At the moment of signing the grant contract, it is obligatory for organization to implement project in such way that has planned it. If these project activities are implemented in accordance with the applicable legislation, the funds, used by the beneficiary will be reimbursed.

Therefore the situation on the start-up companies is contradictory: from one hand the willing of European Commission to use as many financial instruments as possible in order to have more added value. On the other hand is the difficulties and in many cases the impossibility to access finance, due to the lack of experience of the company, the insignificant assets they have, the inability to secure the normal business loan that marks the investments as a high risk.

\section{Conclusions}

We should not treat the start-ups with the pure market understanding, especially when we consider start-ups in key priority sectors such as high-technologies. Sometimes small flexible team with untraditional thinking could create genius idea that could be at the center of total rearrangement of the whole industry. This is the right direction for European economy in order to ensure good level of competitiveness on the global scale.

\section{References}

[1] Cole, R., Sokolyk., T., Debt financing, survival, and growth of start-up firms, Journal of Corporate Finance, Available online - November 2017.

[2] Hasani, T., Bojei, J., Dehghantanha, A., Investigating the antecedents to the adoption of SCRM technologies by start-up companies, Telematics and Informatics, Volume 34, Issue 5, August 2017, Pages 655-675.

[3] Laary-Salmela, S., Mainela, T., Puhakka, V., Resolving the start-up identity crisis: Strategizing in a network context, Industrial Marketing Management, online Available online - December 2017.

[4] McGrath, H., Medlin, C., O'Toole, T., A process-based model of network capability development by a start-up firm, Industrial Marketing Management, Available online 8 December 2017.

[5] Shih, T., Aaboen, L., The network mediation of an incubator: How does it enable or constrain the development of incubator firms' business networks?, Industrial Marketing Management, Available online 7 December 2017.

[6] Pajares, J., Lopez-Paredes, A., Hernandez, C., Technology Start-up Firms as a Portfolio of Projects: The Case of DIMA 3D, Procedia - Social and Behavioral Sciences, Volume 226, 14 July 2016, Pages 59-66.

[7] Rasmussen, E., Tanev, S., Start-Up Creation, The Smart Eco-Efficient Built Environment, 2016, Pages 39-56.

[8] National Strategy for SMEs Promotion - Small Business Act for the period 2014-2020.

[9] Operational Programme Innovation and Competitiveness 2014-2020.

[10] http://www.bulnao.government.bg/en/articles/bulgaria-has-achieved-96-absorption-rateof-eu-financial-instruments-and-ranks-7th-within-the-european-union-1762. 